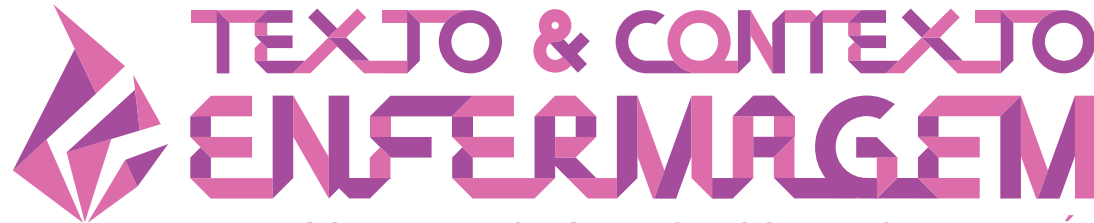

TEXT \& CONTEXT NURSING TEXTO \& CONTEXTO ENFERMERÍA

\section{HPV VACCINE ADHERENCE AMONG ADOLESCENTS: INTEGRATIVE REVIEW}

\author{
Ayla Maria Calixto de Carvalho \\ Elaine Maria Leite Rangel Andrade ${ }^{2}$ \\ Lídya Tolstenko Nogueira² \\ Telma Maria Evangelista de Araújo²
}

1Universidade Federal do Piauí, Programa de Pós-Graduação em Enfermagem. Teresina, Piauí, Brasil. 2Universidade Federal do Piauí, Nursing Department. Teresina, Piauí, Brasil.

\begin{abstract}
Objective: to identify what factors are connected to adolescent adherence to the vaccination against Human Papillomavirus.

Method: integrative developed using the following data base: Medical Literature Analysis and Retrieval System Online and Web of Science, Cumulative Index to Nursing and Allied Health Literature, Literatura Latino-Americana e do Caribe em Ciências da Saúde (Latin-American and Caribbean Literature in Health Sciences), and Base de dados de Enfermagem (Nursing Database); using the descriptors and keywords: Papillomaviridae, immunization, vaccines. The final sample had 31 original articles.

Result: Vaccine adherence predictors were identified as: knowledge about virus infection risk, vaccination and its benefits; cervical cancer and genital warts prevention; sexual activity; being over 14 years old; mothers' intention to adhere to vaccination; mother-child communication about sexually transmitted infections, contraception and condoms; vaccination offered in school; recommendation by teachers and health professionals; vaccine safety and effectiveness.

Conclusion: Evidence points towards the necessity to redesign the presentation strategy of the vaccine, because despite the cultural differences among the countries where the studies were carried out, it is noticeable that society shelters adolescents aged from 10 to 14 years old, considering it early for sexual initiation and presenting difficulties to broach sexuality-related topics with children.
\end{abstract}

DESCRIPTORS: Papillomaviridae. Immunization. Vaccines. Adolescent. Nursing. 


\section{ADESÃO À VACINA HPV ENTRE OS ADOLESCENTES: REVISÃO INTEGRATIVA}

\section{RESUMO}

Objetivo: identificar os fatores associados à adesão de adolescentes à vacina contra o Papilomavírus Humano.

Método: trata-se de revisão integrativa da literatura realizada nas bases de dados Medical Literature Analysis and Retrieval System Online e Web of Science, Cumulative Index to Nursing and Allied Health Literature, Literatura Latino-Americana e do Caribe em Ciências da Saúde, Base de dados de Enfermagem, utilizando os descritores e palavras-chave: adolescente, Papillomaviridae, imunização, vacinas. A amostra final foi de 31 artigos originais.

Resultado: foram identificados como preditores de adesão à vacina: o conhecimento quanto ao risco de infecção pelo vírus, da vacina e seus benefícios; a prevenção do câncer de colo de útero e de verrugas genitais; atividade sexual; idade acima de 14 anos; intenção das mães em aderir à vacinação; a comunicação entre mãe e filho sobre infecção sexualmente transmissível, contracepção e preservativo; oferta da vacina na escola; recomendação por professores e profissionais da saúde; segurança e eficácia da vacina.

Conclusão: as evidências apontam para a necessidade de reformular a estratégia de apresentação da vacina, apesar das diferenças culturais dos países em que os estudos ocorreram, se percebe que a sociedade cerca de cuidados os adolescentes de 10 a 14 anos, considera cedo para a iniciação sexual e tem dificuldade em abordar com os filhos assuntos relacionados à sexualidade.

DESCRITORES: Papillomaviridae. Imunização. Vacinas. Adolescente. Enfermagem.

\section{ADHESIÓN A LA VACUNA DEL VPH ENTRE ADOLESCENTES: REVISIÓN INTEGRATIVA}

\section{RESUMEN}

Objetivo: identificar factores asociados con la adherencia de los adolescentes a la vacuna contra el virus del papiloma humano.

Método: revisión integral de la literatura en el Medical Literature Analysis and Retrieval System Online y Web of Science, Cumulative Index to Nursing and Allied Health Literature, Literatura Latino-Americana y del Caribe en Ciencias de la Salud, Base de dados de Enfermería utilizando descriptores y palabras clave: adolescente, Papillomaviridae, inmunización, vacunas. La muestra final consistió en 31 artículos originales.

Resultado: se identificaron los siguientes predictores de adherencia a la vacuna: conocimiento del riesgo de infección viral, vacuna y sus beneficios; la prevención del cáncer cervical y las verrugas genitales; actividad sexual edad mayor de 14 años; intención de las madres de adherirse a la vacunación; comunicación madrehijo sobre infección de transmisión sexual, anticoncepción y condones; oferta de vacuna en la escuela; recomendación de docentes y profesionales de la salud; seguridad y eficacia de la vacuna.

Conclusión: la evidencia apunta a la necesidad de reformular la estrategia de presentación de la vacuna, a pesar de las diferencias culturales en los países en los que se realizaron los estudios. Está claro que la sociedad se preocupa por los adolescentes de 10 a 14 años, lo considera temprano para el inicio sexual y tiene dificultades para abordar problemas relacionados con la sexualidad con niños.

DESCRIPTORES: Papillomaviridae. Inmunización. Vacunas. Adolescente. Enfermería. 


\section{INTRODUCTION}

World Health Organization (WHO) recommends the use of vaccines against Human Papillomavirus (HPV), with priority immunization for the population of girls aged between 9 and 14 years, before they become sexually active. Evidence suggests that vaccine coverage among girls $(>80 \%)$ lowers the risk of HPV infection to boys. Vaccines offer immunogenicity and effectiveness for cervical cancer prevention, which is mainly caused by HPV 16 and 18 . The recommended vaccination schedule comprises two doses with a six-month lapse between the first and second doses, for the patients aged 9 to 14 years. A lapse under 12-15 months is suggested to complete the vaccination schedule before the individual becomes sexually active. In case the lapse between doses is under five months, a third dose must be had at least six months after the first dose. A three-dose vaccination schedule $(0,1-2,6$ months $)$ is recommended for patients over 15 years old and for people who are immunocompromised or infected by the immunodeficiency virus (HIV). ${ }^{1}$

HPV causes several kinds of cancer: cervix, vulva, vagina, penis, anus, and oropharynx, as well as anogenital warts. It is estimated that $99 \%$ of cervical cancer cases are connected to HPV, which is avoidable with regular screening tests and HPV vaccines. ${ }^{2}$ In Brazil, overall estimated HPV prevalence is $54.6 \%$, and for high-risk viruses for cancer development, it is $38.4 \% .^{3}$

The vaccine is available in 120 countries, where vaccination strategies were adapted to local reality. Countries that chose an in-school vaccination strategy, such as Australia, Canada and the United Kingdom, have been keeping adequate coverage, whereas countries that offer the vaccine in healthcare establishments present difficulties to reach the recommended goal of at least $80 \%$ coverage. ${ }^{4}$

In Brazil, the vaccine was introduced in 2014. It is available for girls aged 9 to 14 years, and for boys aged 11 to 14 years, with records of low vaccine coverage. Considering the high prevalence of HPV among the youth, the high incidence of cervical cancer, 15.85 cases out of each 100 -thousand women, ${ }^{5}$ added to the documented challenges of vaccine introduction worldwide, ${ }^{6}$ and to the absence of integrative review studies about the literature on associated factors to adolescent adherence to HPV vaccination, this study aims at identifying the factors that are associated to adolescent adherence to the vaccine against HPV.

\section{METHOD}

This study is an integrative review that includes the analysis of relevant research for decision making and clinical practice improvement, making it possible to summarize the state of knowledge about a determined topic, as well as revealing knowledge gaps that have to be filled through the development of new studies. ${ }^{7-8}$

This review followed six steps: 1) development of a research question; 2) sampling or research on primary study literature; 3 ) data extraction of primary studies; 4) assessment of primary studies included in the review; 5) analysis and synthesis of review results; and 6) integrative review presentation. ${ }^{9}$

The research question, "what factors influence adherence to HPV vaccination among adolescents?", was constructed through PICo strategy, whose acronym P.I.Co. stands for Population (P - adolescents), Interest phenomenon (I - adherence to HPV vaccination) and Context of study (Co -associated factors). ${ }^{10}$

The search for primary studies was carried out in the following databases: Cumulative Index to Nursing and Allied Health Literature (CINAHL), Medical Literature Analysis and Retrieval System Online (MEDLINE/PUBMED), Literatura Latino-Americana e do Caribe em Ciências da Saúde (LILACS - Latin-American and Caribbean Literature in Health Sciences), Base de dados de Enfermagem (BDENF - Nursing Database) and Web of Science (WoS); in the timeframe from January 2006 to April 2018. 
During research operationalization, the following search terms were used: Medical Subject Headings (MeSH), Descritores em Ciências da Saúde (DeCS): adolescent, vaccines, immunization, papillomaviridae; CINAHL Titles: adolescent, vaccines, immunization, papillomaviruses; and the keywords (KW): accession, adolescence, teenagers, jovem, juventude, adolescência, socio demographic factor, social factors e demographic factors. In the search strategy, the Boolean operator OR was used, what allowed for research expansion. In chart 1 the research conducted in one of the databases can be found (supplementary document 1 and 2).

Chart 1 - Search strategy on MEDLINE/PUBMED database used on the investigation and selection process of primary studies

\begin{tabular}{|c|c|c|}
\hline PICo & Search strategy & Applied Results \\
\hline$P$ & $\begin{array}{c}\text { ((((“teenagers") OR "adolescent”) OR } \\
\text { "adolescent” [MeSH Terms]) OR "adolescence") } \\
\text { OR "adolescent" [MeSH Terms] }\end{array}$ & \multirow{3}{*}{ 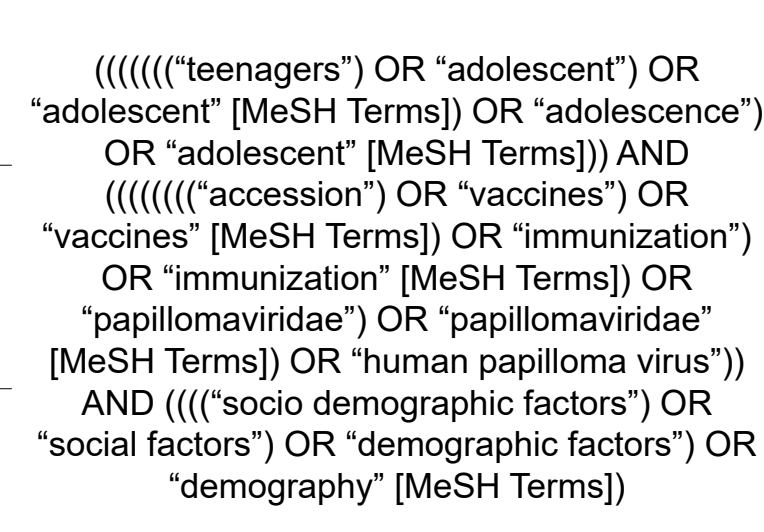 } \\
\hline I & $\begin{array}{c}\text { (((((((“accession”) OR “vaccines”) OR } \\
\text { "vaccines” [MeSH Terms]) OR “immunization”) } \\
\text { OR “immunization” [MeSH Terms]) OR } \\
\text { "papillomaviridae”) OR "papillomaviridae” } \\
\text { [MeSH Terms]) OR "human papilloma virus" }\end{array}$ & \\
\hline Co & $\begin{array}{c}\text { (((“socio demographic factors") OR “social } \\
\text { factors") OR "demographic factors") OR } \\
\text { "demography" [MeSH Terms] }\end{array}$ & \\
\hline
\end{tabular}

As inclusion criteria, the article publication timeframe from January 2006 to April 2018 was established, considering the year of HPV vaccine introduction as a prompt. The adopted exclusion criteria were article duplicates in databases, no identification of relation to the theme, studies with secondary databases, editorials, experience accounts, dissertations and thesis, which were identified by reading article titles and abstracts. The articles were accessed in April 2018.

In each of the databases in use, a specific search strategy was followed and data selection was made by two reviewers independently, aiming at reaching stricter rigor. Thirty-one articles were included, and Picture 1 presents the selection flowchart of those studies.

A form was used for data extraction, containing: title, publication year, study location, database, journal, objective, population/sample, result, conclusion, and evidence level. The studies were sorted according to their evidence level: ${ }^{11}$ Level I - Evidence arising from systematic review or metanalysis of all the randomized controlled trials or rooted in clinical directives based on systematic reviews of randomized controlled trials; Level II - Evidence deriving from at least one well-outlined randomized controlled trial; Level III - Evidence gathered in clearly outlined trials without randomization; Level IV - Evidence arising from cohort studies and of well-outlined case-control studies; Level V - Evidence arising from systematic review of descriptive and qualitative studies; Level VI - Evidence arising from a single descriptive or qualitative study; and Level VII - Specialist opinions, experience accounts, consensus, regulations and legislation. 


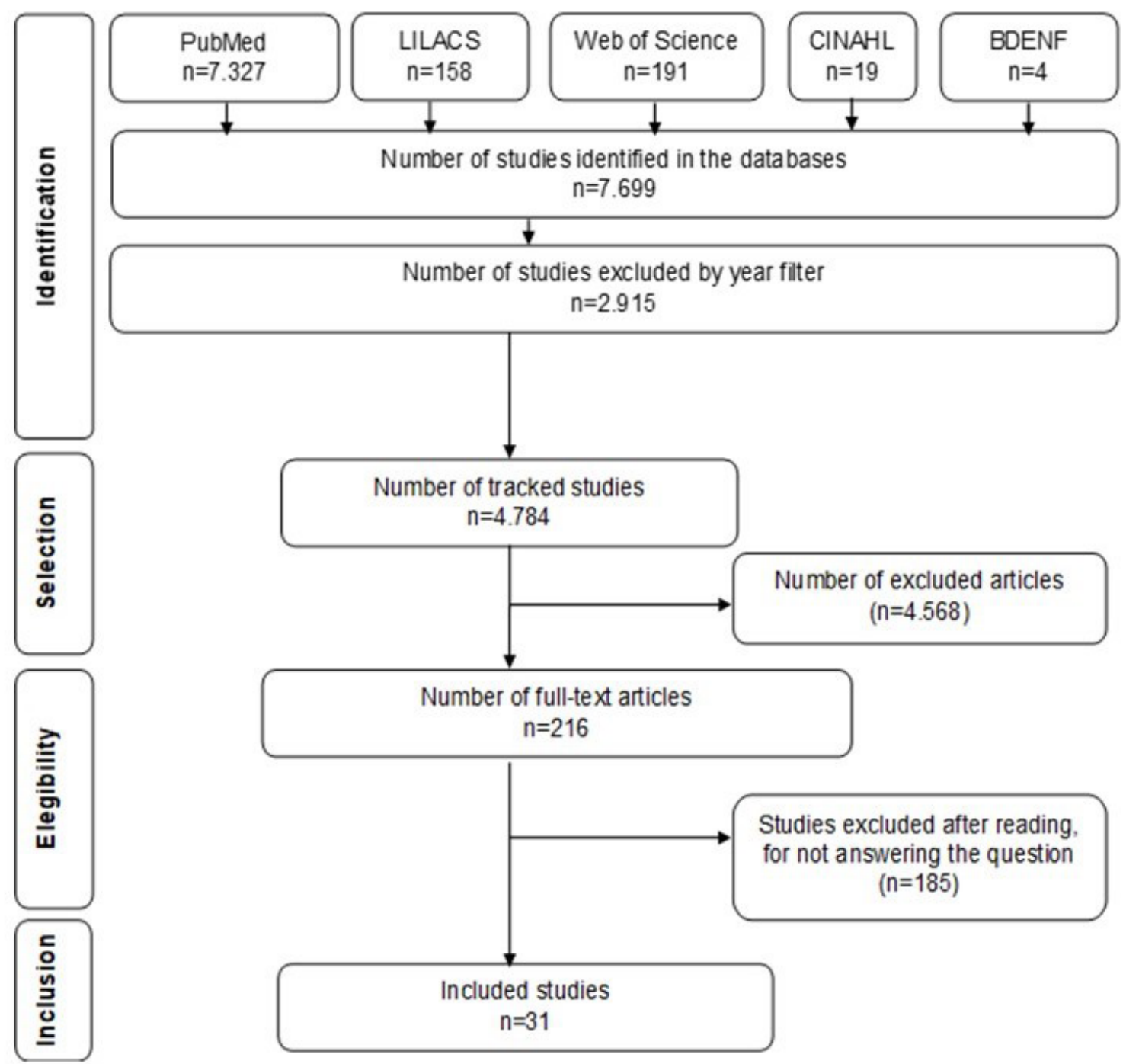

Figure 1 - Study search process

After data extraction, study synthesis was carried out. For discussion, the concept of vulnerability was used, as is in public health. From this perspective, people's exposure to sickness results from three dimensions - individual, programmatic and social. In the individual dimension, there are the knowledge about HPV and the vaccine, behaviors that favor infection, and the ability to take on protective behavior; in the programmatic dimension, there is the access to vaccination in healthcare establishments or in school; and in the social dimension, there is the social space, with its norms, gender relations, and iniquities. ${ }^{12}$ Identified factors were grouped as favoring vaccine adherence or not.

\section{RESULTS}

The 31 studies that comprise this review were carried out from 2006 to 2016 , specifically 6 $(19.3 \%)$ in 2009, 4 (12.9\%) in 2010, 4 (12.9\%) in 2011, $3(9.6 \%)$ in 2007, $3(9.6 \%)$ in 2008, $3(9.6 \%)$ in 2014, 2 (6.5\%) in 2012, 2 (6.5\%) in 2013, 2 (6.5\%) in 2016, $1(3.2 \%)$ in 2006 and $1(3.2 \%)$ in 2015. Regarding study approach, $23(74.2 \%)$ were descriptive quantitative studies and $8(25.8 \%)$ were qualitative ones; concerning evidence level, $23(74.2 \%)$ and $8(25.8 \%)$ reached evidence level IV and VI, respectively. Most studies - 15 (48.4\%) - were made in the United States, while the others are split among other 15 countries (Chart 2). 
Chart 2 - Synthesis of studies by author, country, year, design and evidence level

\begin{tabular}{|c|c|c|}
\hline Author (study country/year) & Study design & $\mathrm{EL}^{*}$ \\
\hline $\begin{array}{l}\text { Ogilvie GS, Remple VP, Marra F, McNeil SA, Naus M, } \\
\text { Pielan K, et al. }{ }^{13} \text { (Canada, 2006-2007) }\end{array}$ & Descriptive & IV \\
\hline $\begin{array}{l}\text { Kwan TTC, Chan KKL, Yip AMW, Tam KF, Cheung ANY, } \\
\text { Young PMC et al. }{ }^{14} \text { (China, 2007) }\end{array}$ & Descriptive qualitative & VI \\
\hline $\begin{array}{l}\text { Read DS, Joseph MA, Polishchuk V, Suss AL. }{ }^{15} \text { (USA, } \\
\text { 2007-2008) }\end{array}$ & Descriptive & IV \\
\hline $\begin{array}{l}\text { Kahn JA, Ding L, Huang B, Zimet GD, Rosenthal SL, } \\
\text { Frazier AL. }{ }^{16} \text { (USA, 2007-2008) }\end{array}$ & Descriptive & IV \\
\hline $\begin{array}{l}\text { Krawczyk A, Knäuper B, Gilca V, Dubé E, Perez S, Joyal- } \\
\text { Desmarais K, et al. }{ }^{17} \text { (Canada, 2008) }\end{array}$ & Descriptive & IV \\
\hline Keenan K, Hipwell A, Stepp, S. ${ }^{18}$ (USA, 2008) & Descriptive & IV \\
\hline Baldwin AS, Bruce CM, Tiro JA. ${ }^{19}$ (USA, 2008-2010) & Descriptive & IV \\
\hline Klötzler A, Kolip P. ${ }^{20}$ (Germany, 2009) & Descriptive qualitative & VI \\
\hline Marlow LA, Wardle J, Waller J. ${ }^{21}$ (United Kingdom, 2009) & Descriptive qualitative & $\mathrm{VI}$ \\
\hline $\begin{array}{l}\text { Tsui J, Singhal R, Rodriguez HP, Gee GC, Glenn BA, } \\
\text { Bastani R.22 (USA, 2009) }\end{array}$ & Descriptive & IV \\
\hline $\begin{array}{l}\text { Glenn BA, Tsui J, Singhal R, Sanchez L, Nonzee NJ, } \\
\text { Chang LC, et al. }{ }^{23} \text { (USA, 2009-2010) }\end{array}$ & Descriptive & IV \\
\hline $\begin{array}{l}\text { Bowyer H, Forster A, Marlow L, Waller J. }{ }^{24} \text { (England, } \\
\text { 2009-2010) }\end{array}$ & Descriptive & IV \\
\hline $\begin{array}{l}\text { Katz IT, Nkala B, Dietrich J, Wallace M, Bekker LG, } \\
\text { Pollenz K, et al. }{ }^{25} \text { (South Africa, 2010) }\end{array}$ & $\begin{array}{l}\text { Descriptive, } \\
\text { multicentric and } \\
\text { qualitative }\end{array}$ & IV \\
\hline $\begin{array}{l}\text { Hanley SJ, Yoshioka E, Ito Y, Konno R, Hayashi Y, Kishi } \\
\text { R, et al. }{ }^{26} \text { (Japan, 2010) }\end{array}$ & Descriptive & IV \\
\hline $\begin{array}{l}\text { Widdice LE, Hoagland R, Callahan ST, Kahn JA, Harrison } \\
\text { CJ, Pahud BA, et al. }{ }^{27} \text { (USA, 2010-2011) }\end{array}$ & Descriptive & IV \\
\hline $\begin{array}{l}\text { Naggar RA, Bobryshev YV, Jashamy K, Musli M. }{ }^{28} \\
\text { (Malasia, 2011) }\end{array}$ & Descriptive & IV \\
\hline $\begin{array}{l}\text { Shao SJ, Nurse C, Michel L, Joseph MA, Suss AL. }{ }^{29} \\
\text { (USA, 2011-2012) }\end{array}$ & Descriptive & IV \\
\hline Khurana S, Sipsma HL, Caskey RN. ${ }^{30}$ (USA, 2011-2012) & Descriptive & IV \\
\hline $\begin{array}{l}\text { Ferrer BH, Trotter CL, Hickman M, Audrey S. }{ }^{31} \text { (England, } \\
\text { 2012-2013) }\end{array}$ & Descriptive qualitative & VI \\
\hline $\begin{array}{l}\text { Onyeabor OS, Martin N, Orish VN, Sanyaolu AO, } \\
\text { Iriemenam NC. }{ }^{22} \text { (USA, 2013) }\end{array}$ & Descriptive qualitative & VI \\
\hline $\begin{array}{l}\text { Thomas TL, Strickland OL, DiClemente R, Higgins M, } \\
\text { Haber M. }{ }^{33} \text { (USA, 2010-2011 }\end{array}$ & Descriptive & IV \\
\hline $\begin{array}{l}\text { Hanley SJ, Yoshioka E, Ito Y, Konno R, Sasaki Y, Kishi R, } \\
\text { et al. }{ }^{34} \text { (Japan, 2010) }\end{array}$ & Descriptive & VI \\
\hline $\begin{array}{l}\text { Gross TT, Laz TH, Rahman M, Berenson AB. }{ }^{35} \text { (USA, } \\
\text { 2011-2013) }\end{array}$ & Descriptive & IV \\
\hline $\begin{array}{l}\text { Alder S, Gustafsson S, Perinetti C, Mints M, Sundström } \\
\text { K, Andersson S. }{ }^{36} \text { (Argentina, 2012) }\end{array}$ & Descriptive & IV \\
\hline $\begin{array}{l}\text { Kepka D, Warner EL, Kinney AY, Spigarelli MG, Mooney } \\
\text { K. }{ }^{37} \text { (USA, 2013) }\end{array}$ & Descriptive qualitative & VI \\
\hline $\begin{array}{l}\text { Kruiroongroj S, Chaikledkaew U, Thavorncharoensap } \\
\text { M. }{ }^{38} \text { (Thailand, 2013) }\end{array}$ & Descriptive & IV \\
\hline
\end{tabular}


Chart 2 - Cont.

\begin{tabular}{|lcc|}
\hline \multicolumn{1}{|c|}{ Author (study country/year) } & Study design & EL* $^{*}$ \\
\hline $\begin{array}{l}\text { Lee H, Kim M, Kiang P, Shi, L, Tan K, Chea P, et al. }{ }^{39} \\
\text { (USA, 2014) }\end{array}$ & Descriptive \\
\hline $\begin{array}{l}\text { Ogunbajo A, Hansen CE, North AL, Okoloko E, Niccolai } \\
\text { LM. }^{40} \text { (USA, 2014) }\end{array}$ & Descriptive qualitative & VI \\
\hline $\begin{array}{l}\text { Alberts CJ, Van der Loeff MF, Hazeveld Y, Melker HE, } \\
\text { Van der Wal MF, Nielen A, et al. }{ }^{41} \text { (Netherlands, 2014) }\end{array}$ & Descriptive & IV \\
\hline $\begin{array}{l}\text { Lee KN, Chang KH, Cho SS, Park SH, Park ST. }{ }^{42} \text { (South } \\
\text { Korea, 2016) }\end{array}$ & Descriptive & IV \\
\hline $\begin{array}{l}\text { Abou El-Ola MJ, Rajab MA, Abdallah DI, Fawaz IA, Awad } \\
\text { LS, Tamim HM, et al. } .^{43} \text { (Lebanon, 2016) }\end{array}$ & Descriptive & IV \\
\hline
\end{tabular}

${ }^{*}$ EL: Evidence level

The studies identified factors associated to HPV vaccine adherence or its lack, $67.7 \%$ verse about adherence and $54.8 \%$ about non-adherence. In $22.6 \%$ of studies, both adherence and nonadherence to HPV vaccine were broached (Chart 3 ).

Chart 3 - Synthesis of studies by factors associated to HPV vaccine adherence

\begin{tabular}{|c|c|}
\hline Factors associated to HPV vaccine adherence & $\begin{array}{c}\text { Factors associated to HPV vaccine } \\
\text { non-adherence }\end{array}$ \\
\hline Health professionals' recommendation..$^{13}$ & \multirow{2}{*}{$\begin{array}{l}\text { Limited knowledge about cervical cancer and HPV; } \\
\text { high cost of vaccination; uncertain effectiveness } \\
\text { duration; low perceived risk of infection; and fear of } \\
\text { injection pain. }{ }^{14}\end{array}$} \\
\hline $\begin{array}{l}\text { Family perception about HPV risk, friends' support } \\
\text { and medical reassurance about vaccine safety and } \\
\text { effectiveness. } .^{14}\end{array}$ & \\
\hline \multirow{2}{*}{$\begin{array}{l}\text { Sexual activity; knowledge about HPV as an } \\
\text { etiological agent of cervical cancer. }{ }^{15}\end{array}$} & Age under 13 years. ${ }^{16}$ \\
\hline & Lack of knowledge about vaccine safety. ${ }^{17}$ \\
\hline $\begin{array}{l}\text { Susceptibility perception of HPV infection and } \\
\text { knowing vaccine benefits. }{ }^{17}\end{array}$ & $\begin{array}{l}\text { Being black among minorities; lack of information } \\
\text { about public funding for vaccination. } .^{18}\end{array}$ \\
\hline Intimate sexual behavior in the previous year. ${ }^{18}$ & No social circle to talk about the vaccine. ${ }^{19}$ \\
\hline $\begin{array}{l}\text { Recommendation by doctors and inter-personal } \\
\text { sources. }{ }^{19}\end{array}$ & $\begin{array}{l}\text { Belief in a lack of vulnerability to cervical cancer; } \\
\text { fear of vaccine adverse events. } .^{20}\end{array}$ \\
\hline $\begin{array}{l}\text { Protection against cervical cancer; gynecologists' } \\
\text { recommendation. }{ }^{20}\end{array}$ & $\begin{array}{l}\text { Fear of vaccine adverse effects; age under } 13 \\
\text { years; religious beliefs and low perceived risk of } \\
\text { HPV infection. }{ }^{21}\end{array}$ \\
\hline Easier geographic access to vaccination services. ${ }^{22}$ & $\begin{array}{l}\text { Lack of knowledge about HPV, not speaking the } \\
\text { local language, and absence of health insurance. } .^{23}\end{array}$ \\
\hline $\begin{array}{l}\text { Belief in the protection offered by vaccines, health } \\
\text { professionals' recommendations and impact on } \\
\text { sexual practice. } .^{23}\end{array}$ & $\begin{array}{l}\text { Being black or belonging to other ethnical } \\
\text { minorities. }{ }^{24}\end{array}$ \\
\hline Teenagers with autonomy for decision making & \multirow{2}{*}{$\begin{array}{l}\text { Being black, smoking, lack of access to primary } \\
\text { health consultations and to health insurance. }{ }^{27}\end{array}$} \\
\hline $\begin{array}{l}\text { Knowledge about HPV infection and its relation with } \\
\text { cervical cancer. }{ }^{26}\end{array}$ & \\
\hline \multirow{2}{*}{$\begin{array}{l}\text { Age (the older ones), being white, low income, } \\
\text { knowledge about cervical cancer, about the vaccine } \\
\text { and where it is offered. Recommendation by } \\
\text { teachers and health professionals. }{ }^{28}\end{array}$} & Habitual use of condoms. ${ }^{29}$ \\
\hline & \multirow{2}{*}{$\begin{array}{l}\text { Lack of parental consent, related to beliefs and } \\
\text { values about sexual activity, to education and to } \\
\text { language barriers. }{ }^{31}\end{array}$} \\
\hline Increase in the number of sexual pa & \\
\hline
\end{tabular}


Chart 3 - Cont.

\begin{tabular}{|c|c|}
\hline Factors associated to HPV vaccine adherence & $\begin{array}{l}\text { Factors associated to HPV vaccine } \\
\text { non-adherence }\end{array}$ \\
\hline $\begin{array}{l}\text { Vaccine protection against genital warts; knowing a } \\
\text { relative or friend who is vaccinated; sexual activity; } \\
\text { knowing somebody with genital warts. }{ }^{30}\end{array}$ & $\begin{array}{l}\text { Lack of knowledge about potential risks of HPV } \\
\text { among men who have sex with other men and about } \\
\text { HPV vaccine. }{ }^{32}\end{array}$ \\
\hline $\begin{array}{l}\text { Vaccine offered in school; knowledge about } \\
\text { infection risks and cervical cancer prevention. }{ }^{31}\end{array}$ & Lack of knowledge about HPV. ${ }^{34}$ \\
\hline Culture, religion and faith influence the decision. ${ }^{33}$ & $\begin{array}{l}\text { Lack of knowledge about the vaccine among } \\
\text { parents. } .^{37}\end{array}$ \\
\hline $\begin{array}{l}\text { Mother-child communication about sexually } \\
\text { transmitted infections, contraception and } \\
\text { condoms. }{ }^{35}\end{array}$ & $\begin{array}{l}\text { Limited knowledge about HPV and the vaccine } \\
\text { among parents. }{ }^{38}\end{array}$ \\
\hline Mothers' acceptance of the vaccine. ${ }^{36}$ & dverse events associated to the vaccine..$^{42}$ \\
\hline Knowledge about HPV. ${ }^{39}$ & \multirow{3}{*}{$\begin{array}{l}\text { Mothers' lack of knowledge about the vaccine, } \\
\text { uncertainty about its safety or effectiveness, worries } \\
\text { about future sex life and vaccine costs. }{ }^{43}\end{array}$} \\
\hline $\begin{array}{l}\text { HPV vaccine offer as part of the adolescent's } \\
\text { vaccination schedule, with the additional benefit of } \\
\text { cancer prevention. }{ }^{40}\end{array}$ & \\
\hline Mothers' acceptance of the vaccine. ${ }^{41}$ & \\
\hline
\end{tabular}

\section{DISCUSSION}

The articles that were included in this integrative review varied in methodological design and sample size. Each one of the studies had limitations and the results of each research must be interpreted with care, with findings that represent specific communities, which cannot be generalized. The studies were carried out with parents (61.2\%); ${ }^{13,16-17,19,21-23,26,33-43}$ adolescents (25.8\%); ${ }^{; 1-15,18,20,24,28,31-32}$ and both (13.0\%). ${ }^{25,27,29-30}$ They hold scientific evidence level IV $(74.6 \%)^{13,15-19,22-30,33,35-36,38-39,41-43}$ and VI $(25.8 \%),{ }^{14,20-21,31-32,34,37,40}$ what accredits them as safe information sources to subsidize understanding of vaccination against HPV. Furthermore, the many factors associated to adherence or non-adherence to vaccination against HPV are presented below, grouped in individual, programmatic and social dimensions.

\section{Factors associated to adherence to vaccination against HPV in the individual dimension}

In the individual dimension, the following factors were identified as associated to adherence to vaccination against HPV: knowledge about the HPV infection risk; cervical cancer and genital warts prevention; age over 14 years; knowing the vaccine and its benefits; mothers' intention to adhere to vaccination; mother-child communication about sexually transmitted infection, contraception and condoms. And as non-adherence factors: smoking, habitual use of condoms, adverse events, pain related to vaccine injection, low perceived risk of HPV infection.

Vaccine adherence was associated to parents' and adolescents' knowledge about HPV and vaccination. Among the information contributing to that, there is a highlight to the relation between HPV infection and cervical cancer, ${ }^{15,20,35}$ and the prevention of genital warts among male adolescents. ${ }^{29-30,32,38}$

In Brazil, the vaccine is offered to nine-year-olds onwards, in order to promote protection before sexual initiation and, usually, it is associated to parents' disposition to allow vaccination, therefore it is necessary that they be informed about HPV infection, the vaccine and its benefits, so they can safely decide about vaccination..$^{26,38-39,41}$. This could diminish unfavorable opinions about the vaccine against HPV, increase its acceptance and vaccination schedule conclusion, especially among people who 
associate the vaccine to change in sexual behavior, early sexual initiation, and increased number of partners. ${ }^{13,16}$

Parents' refusal was related to non-adherence to the vaccine against HPV in association to fear of adverse events. ${ }^{17,42}$ Recent studies related to vaccination against HPV concluded that the vaccine is well tolerated, without serious side effects. Because it is among parents' concerns, at the moment to consent with vaccination or not, more efforts must be made to help them understand risks and clarify the low probability of complications and more severe reactions. ${ }^{17}$

It was observed that adolescents are more involved in the decision to be vaccinated at 14 years old and onwards, when they are in a relationship and have initiated sexual life. ${ }^{14,16,29-30,32}$ Meanwhile, risk perception for HPV is lower among the following groups: smokers; sexually active ones who wear condoms; and those who have not initiated sexual life, so vaccination is postponed among them ${ }^{15,18}$.

\section{Factors associated to adherence to vaccination against HPV in the programmatic dimension}

In the programmatic dimension, the adherence factors were: vaccination offered in school, teachers' and health professionals' recommendations, medical reassurance about vaccine safety and effectiveness, vaccine offer as part of the adolescent's vaccination schedule.

Coverage against HPV is high when the vaccine is offered in the school environment. ${ }^{28,31}$ In this context, teachers have an influential role to convince students about getting the vaccine, alongside health professionals. For successful vaccine implementation, information must be extended to parents who, with the advice of a health professional, present positive attitudes regarding vaccination, what increases acceptance and lowers perceived barriers, including vaccine costs and safety. ${ }^{13,28}$

Regarding vaccine offers in healthcare establishments, it was found that living near the services is not associated to the beginning of vaccination schedules against HPV, whereas promotion of places where the vaccine is available is more relevant. ${ }^{22}$

Among vaccine introduction strategies for parents, it is recommendable to include the vaccine against HPV in adolescents' vaccination schedule, because that makes it easier to understand that vaccine is like the other available ones, it is able to prevent diseases, it is provided in the same environment as all others, because parents who believe vaccines protect children's health are more inclined to accept vaccination against HPV. ${ }^{26,36,40}$

\section{Factors associated to adherence to vaccination against HPV in the social dimension}

In the social dimension, adherence is related to family perception and friends' support, and access to information about the vaccine with people within the adolescent's social circles. Nonadherence is related to ethnicity, religion, faith, beliefs and values about sexual behavior, to fear that the vaccine will not be accepted by other family members or unnecessary due to low risk of HPV infection, to access to education, and to not speaking the language of the country of residence.

Among adherence factors, parents' social circles are an important source of information about the vaccine and they present higher credibility than information promoted in mass media. ${ }^{19}$

In communities under social vulnerability, adolescents mature earlier and hold autonomy over decision making, therefore they must be involved in the offer of vaccination against HPV. ${ }^{25}$ Meanwhile, in other communities, the decision to get a vaccine is made by the parents, who show concerns about the vaccine against HPV, religious and cultural norms, the family lifestyle and the belief that adolescents are protected against HPV infection and cervical cancer, what influences the decision to refuse vaccination..$^{21,33,43}$ 
Among adolescents who belong to groups living in unfavorable social environments, who are black, who have no health insurance or no access to public healthcare, who are not proficient in the language of the place where they live, ${ }^{18,23-24,27,31,37}$ educational interventions must be reformulated and take local culture into account because it interferes with people's perceptions about risk, in order to influence a behavioral change and promote adherence to the vaccine against HPV.

Therefore, health education activity is a tool that must be incentivized and developed by health professionals, because it allows adolescents and their parents to play active roles in the learning process, with critical-reflexive view of the reality where they belong. ${ }^{44}$ In that health education proposal, it is important to build institutional partnerships, such as the one between health and education, aiming at promoting healthy behaviors. ${ }^{45}$ Thus, conversation between parents and their children may be encouraged, so it is not reduced to information relay, with no depth to health themes that are relevant to that age, such as prevention, sex and sexually transmitted infections.

In that sense, educational technologies focusing HPV, videos, messages in electronic devices and printed material need to be developed, considering local culture, with adequate language to reach parents' and adolescents' understanding about the virus and the vaccine, in order to contribute to the adherence to and completion of the recommended vaccination schedule. ${ }^{46}$

It must be highlighted that the identified studies did not present a strong level of evidence, what translates into a necessity for the development of studies with stronger evidence.

\section{CONCLUSION}

Among the factors that reinforce adherence to vaccination against HPV, in the individual dimension, there were: knowledge about HPV infection, its relation with cervical cancer and genital warts, vaccine safety and effectiveness; in the programmatic dimension: vaccine offer in school, and teacher's and health professionals' recommendations; and, in the social dimension: family perception about HPV risk and support of social circles. Thus, identifying the factors associated to adolescents' adherence to the vaccine, according to the vulnerability dimensions, makes it possible to highlight the points that need intervention to improve vaccine coverage.

Factors to non-adherence to vaccination were found, such as: low perceived risk of HPV infection, race, beliefs and values about sexual behavior. Evidence points to the necessity to reformulate the vaccine introduction strategy, for the community at large and for health professionals. It is necessary to unlink the vaccine to sexual initiation, despite cultural differences in the countries where the studies were carried out. It is noticeable that society shelters adolescents in the first phase, from 10 to 14 years old, considering it early for sexual initiation and presenting difficulties to broach subjects related to sexuality with their children.

Therefore, in order to support parents and adolescents in the decision to accept vaccination against HPV, information about the virus, the vaccine and its benefits must be reintroduced in context and respecting local culture. 


\section{REFERENCES}

1. World Health Organization (WHO). Human papillomavirus vaccines: WHO position paper. May 2017 - Recommendations. Vaccine [Internet]. 2017 [cited 2018 Feb 03]; 35(43):5753-55. Available from: https://www.ncbi.nlm.nih.gov/pubmed/28596091

2. Lee H, Kim M, Cooley ME, Kiang PNC, Tang S, Shi L, et al. Development of a theory-guided storytelling narrative intervention to improve HPV vaccination behavior: Save our daughters from cervical cancer. Appl Nurs Res [Internet]. 2017 [cited 2018 Feb 03]; 34:57-61. Available from: https://linkinghub.elsevier.com/retrieve/pii/S089718971630372X

3. Ministério da Saúde (BR). Estudo POP-Brasil: resultados e ações para o enfrentamento da infecção pelo HPV. Dados preliminares do projeto POP-Brasil-Estudo Epidemiológico sobre a Prevalência Nacional de Infecção pelo HPV [Internet]. Porto Alegre (BR): MS; 2017. [cited 2018 June 10]. Available from: http://www.iepmoinhos.com.br/pesquisa/downloads/LIVROPOP_Brasil_-_Resultados_Preliminares.pdf

4. Salazar LJ, Benavides MR, Boogaard S, Marín Y. Estrategias latinoamericanas para la vacunación contra el virus del papiloma humano - una revisión temática. Hacia Promoc Salud [Internet]. 2017 Dec [cited 2018 Feb 24]; 22(2):129-43. Available from: http://dx.doi.org/10.17151/hpsal.2017.22.2.10

5. Sousa PDL, Takiuti AD, Baracat EC, Sorpreso ICE, Abreu LC. Knowledge and acceptance of HPV vaccine among adolescents, parents and health professionals: construct development for collection and database composition. J Hum Growth Dev [Internet]. 2018 [cited 2018 Feb 24]; 28(1):58-68. Available from: https://dx.doi.org/10.7322/jhgd.143856

6. Newman PA, Logie $\mathrm{CH}$, Lacombe-Duncan A, et al. Parents' uptake of human papillomavirus vaccines for their children: a systematic review and meta-analysis of observational studies. BMJ Open [Internet]. 2018 [cited 2018 Feb 24]; 8:e019206. Available from: https://dx.doi.org/10.1136/ bmjopen-2017-019206

7. Polit DF, Beck CT. Fundamentos de Pesquisa em Enfermagem: avaliação de evidências para as práticas da Enfermagem. 7th ed. Porto Alegre (BR): Artmed; 2011.

8. Whittemore R, Knafl K. The integrative review: updated methodology. J Adv Nurs [Internet]. 2005 [cited 2018 May 26]; 52(5):546-53. Available from: https://dx.doi.org/10.1111/j.13652648.2005.03621.x

9. Galvão CM, Mendes KDS, Silveira RCC. Revisão Integrativa: método de revisão para sintetizar as evidências disponíveis na literatura. In: Brevidelli MM, Sertório SCM. Trabalho de conclusão de curso: guia prático para docentes e alunos da área da saúde. São Paulo(BR): látrica; 2010.

10. Aromataris E, Munn Z, editors. Joanna Briggs Institute Reviewer's Manual. The Joanna Briggs Institute; 2017 [cited 2018 Nov 17]. Available from: https://reviewersmanual.joannabriggs.org/

11. Melnyk BM, Fineout-Overholt E. Making the case for evidence-based practice. In: Melnyk BM, Fineout-Overholt E. Evidence-based practice in nursing \& healthcare. A guide to best practice. Philadelphia (US): Lippincot Williams \& Wilkins; 2015. p.3-24.

12. Bertolozzi MR, Nichiata LYI, Takahashi RF, Ciosak SI, Hino P, Val LF et al. The vulnerability and the compliance in Collective Health. Rev Esc Enferm USP [Internet]. 2009 Dec [cited 2018 May 27]; 43(spe2):1326-30. Available from: https://dx.doi.org/10.1590/S0080-62342009000600031.

13. Ogilvie GS, Remple VP, Marra F, McNeil SA, Naus M, Pielan K, et al Intention of parents to have male children vaccinated with the human papillomavirus vaccine Sexually Transmitted Infections [Internet]. 2008 [cited 2018 May 26]; 84:318-23. Available from: http://sti.bmj.com.ez17.periodicos. capes.gov.br/content/84/4/318.citation-tools 
14. Kwan TTC, Chan KKL, Yip AMW, Tam KF, Cheung ANY, Young PMC et al. Barriers and facilitators to human papillomavirus vaccination among Chinese adolescent girls in Hong Kong: a qualitativequantitative study Sexually Transmitted Infections [Internet]. 2008 [cited 2018 May 26]; 84:227-32. Available from: https://www.ncbi.nlm.nih.gov/pubmed/18256106

15. Read DS, Joseph MA, Polishchuk V, Suss AL. Attitudes and perceptions of the HPV vaccine in Caribbean and African-American adolescent girls and their parents. J Pediatr Adolesc Gynecol [Internet]. 2010 Aug [cited 2018 May 26]; 23(4):242-5. Available from: https://www-sciencedirectcom.ez17.periodicos.capes.gov.br/science/article/pii/S1083318810000768?via\%3Dihub

16. Kahn JA, Ding L, Huang B, Zimet GD, Rosenthal SL, Frazier AL. Mothers' intention for their daughters and themselves to receive the human papillomavirus vaccine: a national study of nurses. Pediatrics [Internet]. 2009 June [cited 2018 May 26]; 123(6):1439-45. Available from: https://doi-org.ez17.periodicos.capes.gov.br/10.1542/peds.2008-1536

17. Krawczyk A, Knäuper B, Gilca V, Dubé E, Perez S, Joyal-Desmarais K, et al. Parents decisionmaking about the human papillomavirus vaccine for their daughters: I. Quantitative results. Human Vaccines \& Immunotherapeutics [Internet]. 2015 [cited 2018 May 26]; 11(2):322-9. Available from: http://doi.org/10.1080/21645515.2014.1004030.

18. Keenan K, Hipwell A, Stepp S. Race and Sexual Behavior Predict Uptake of the Human Papillomavirus Vaccine. Health Psychology [Internet]. 2012 Jan [cited 2018 May 26]; 31(1):314. Available from: http://doi-org.ez17.periodicos.capes.gov.br/10.1037/a0026812

19. Baldwin AS, Bruce CM, Tiro JA. Understanding how mothers of adolescent girls obtain information about the human papillomavirus vaccine: associations between mothers' health beliefs, information seeking, and vaccination intentions in na ethnically diverse sample. J Health Psychol [Internet]. 2013 Jul [cited 2018 May 26]; 18(7):926-38. Available from: http://doi-org.ez17.periodicos.capes. gov.br/10.1177/1359105312445078

20. Klötzler A, Kolip P. Decision for or against HPV vaccination - a qualitative study with adolescent girls. Gesundheitswesen [Internet]. 2012 Nov [cited 2018 May 26]; 74(11):716-21. Available from: https://www.ncbi.nlm.nih.gov/pubmed/22012564

21. Marlow LA, Wardle J, Waller J. Attitudes to HPV vaccination among ethnic minority mothers in the UK: an exploratory qualitative study. Hum Vaccin [Internet]. 2009 Feb [cited 2018 May 26];5(2):105-10. Available from: https://dx.doi.org/10.4161/hv.5.2.7368

22. Tsui J, Singhal R, Rodriguez HP, Gee GC, Glenn BA, Bastani R. Proximity to safety-net clinics and HPV vaccine uptake among low-income, ethnic minority girls. Vaccine [Internet]. $2013 \mathrm{Apr}$ 12 [cited 2018 May 26]; 31(16):2028-34. Available from: http://doi-org.ez17.periodicos.capes. gov.br/10.1016/j.vaccine.2013.02.046

23. Glenn BA, Tsui J, Singhal R, Sanchez L, Nonzee NJ, Chang LC, et al. Factors associated with HPV awareness among mothers of low-income ethnic minority adolescent girls in Los Angeles. Vaccine [Internet]. 2015 Jan 3 [cited 2018 May 26]; 33(2):289-93. Available from: http://doi-org. ez17.periodicos.capes.gov.br/10.1016/j.vaccine.2014.11.032

24. Bowyer $\mathrm{H}$, Forster A, Marlow L, Waller J. Predicting human papillomavirus vaccination behaviour among adolescent girls in England: Results from a prospective survey. J Fam Plann Reprod Health Care [Internet]. 2014 [cited 2018 May 26]; 40(1):14-22. Available from: http://dx.doi-org. ez17.periodicos.capes.gov.br/10.1136/jfprhc-2013-100583

25. Katz IT, Nkala B, Dietrich J, Wallace M, Bekker LG, Pollenz K, et al. A Qualitative Analysis of Factors Influencing HPV Vaccine Uptake in Soweto, South Africa among Adolescents and Their Caregivers. PLoS ONE [Internet]. 2013 [cited 2018 May 26]; 8(8):e72094. Available from: http:// doi-org.ez17.periodicos.capes.gov.br/10.1371/journal.pone.0072094 
26. Hanley SJ, Yoshioka E, Ito Y, Konno R, Hayashi Y, Kishi R, et al. Acceptance of and attitudes towards human papillomavirus vaccination in Japanese mothers of adolescent girls. Vaccine [Internet]. 2012 Aug 24 [cited 2018 May 26]; 30(39):5740-7. Available from: https://doi-org.ez17. periodicos.capes.gov.br/10.1016/j.vaccine.2012.07.003

27. Widdice LE, Hoagland R, Callahan ST, Kahn JA, Harrison CJ, Pahud BA, et al. Caregiver and adolescent factors associated with delayed completion of the three-dose human papillomavirus vaccination series. Vaccine [Internet]. 2018 Mar 7 [cited 2018 May 26]; 36(11):1491-9. Available from: https://dx.doi.org/10.1016/j.vaccine.2017.12.060UR

28. Naggar RA, Bobryshev YV, Jashamy K, Musli M. Practice of HPV vaccine and associated factors among school girls in Melaka, Malaysia. Asian Pac J Cancer Prev [Internet]. 2012 [cited 2018 May 26];13(8):3835-40. Available from: http:s//dx.doi.org/10.7314/APJCP.2012.13.8.3835

29. Shao SJ, Nurse C, Michel L, Joseph MA, Suss AL. Attitudes and Perceptions of the Human Papillomavirus Vaccine in Caribbean and African American Adolescent boys and Their Parents. J Pediatr Adolesc Gynecol [Internet]. 2015 Oct [cited 2018 May 26]; 28(5):373-7. Available from: https://doi-org.ez17.periodicos.capes.gov.br/10.1016/j.jpag.2014.11.003

30. Khurana S, Sipsma HL, Caskey RN. HPV vaccine acceptance among adolescent males and their parents in two suburban pediatric practices. Vaccine [Internet]. 2015 Mar 24 [cited 2018 May 26]; 33(13):1620-4. Available from: https://doi-org.ez17.periodicos.capes.gov.br/10.1016/j. vaccine.2015.01.038

31. Ferrer $\mathrm{BH}$, Trotter $\mathrm{CL}$, Hickman M, Audrey S. Barriers and facilitators to uptake of the schoolbased HPV vaccination programme in an ethnically diverse group of young women. J Public Health (Oxf) [Internet]. 2016 Sept [cited 2018 May 26]; 38(3):569-77. Available from: https:// doi-org.ez17.periodicos.capes.gov.br/10.1093/pubmed/fdv073

32. Onyeabor OS, Martin N, Orish VN, Sanyaolu AO, Iriemenam NC. Awareness of Human Papillomavirus Vaccine Among Adolescent African American Males Who Have Sex with Males: a Pilot Study. J Racial Ethn Health Disparities [Internet]. 2015 Sept [cited 2018 May 26];2(3):2904. Available from: https://dx.doi.org/10.1007/s40615-014-0068-5DO

33. Thomas TL, Strickland OL, DiClemente R, Higgins M, Haber M. Rural African American parents' knowledge and decisions about human papillomavirus vaccination. J Nurs Scholarsh [Internet]. 2012 Dec [cited 2018 May 26]; 44(4):358-67. Available from: http://doi-org.ez17.periodicos.capes. gov.br/10.1111/j.1547-5069.2012.01479.x

34. Hanley SJ, Yoshioka E, Ito Y, Konno R, Sasaki Y, Kishi R, et al. An exploratory study of Japanese fathers' knowledge of and attitudes towards HPV and HPV vaccination: does marital status matter? Asian Pac J Cancer Prev [Internet]. 2014 [cited 2018 May 26];15(4):1837-43. Available from: https://dx.doi.org/10.7314/apjcp.2014.15.4.1837

35. Gross TT, Laz TH, Rahman M, Berenson AB. Association between mother-child sexual communication and HPV vaccine uptake. Prev Med [Internet]. 2015 May [cited 2018 May 26]; 74:63-6. Available from: http://doi-org.ez17.periodicos.capes.gov.br/10.1016/j.ypmed.2015.03.004

36. Alder S, Gustafsson S, Perinetti C, Mints M, Sundström K, Andersson S. Mothers' acceptance of human papillomavirus (HPV) vaccination for daughters in a country with a high prevalence of HPV. Oncol Rep [Internet]. 2015 May [cited 2018 May 26]; 33(5):2521-8. Available from: https:// dx.doi.org/10.3892/or.2015.3817

37. Kepka D, Warner EL, Kinney AY, Spigarelli MG, Mooney K. Low human papillomavirus (HPV) vaccine knowledge among Latino parents in Utah. J Immigr Minor Health [Internet]. 2015 Feb [cited 2018 May 26]; 17(1):125-31. Available from: https://www-ncbi-nlm-nih-gov.ez17.periodicos. capes.gov.br/pubmed/24609357 
38. Kruiroongroj S, Chaikledkaew U, Thavorncharoensap M. Knowledge, acceptance, and willingness to pay for human papilloma virus (HPV) vaccination among female parents in Thailand. Asian Pac J Cancer Prev [Internet]. 2014 [cited 2018 May 26]; 15(13):5469-74. Available from: https:// www-ncbi-nlm-nih-gov.ez17.periodicos.capes.gov.br/pubmed/25041020

39. Lee H, Kim M, Kiang P, Shi, L, Tan K, Chea P, et al. Factors Associated with HPV Vaccination among Cambodian American Teenagers. Public Health Nurs[Internet]. 2016 [cited 2018 May 26]; 33: 493-501. Available from: https://dx.doi.org/10.1111/phn.12294

40. Ogunbajo A, Hansen CE, North AL, Okoloko E, Niccolai LM. "I think they're all basically the same": parents' perceptions of human papilloma virus (HPV) vaccine compared with other adolescent vaccines. Child Care Health Dev [Internet]. 2016 Jul; [cited 2018 May 26]; 42(4):582-7. Available from: http://doi-org.ez17.periodicos.capes.gov.br/10.1111/cch.12331

41. Alberts CJ, Van der Loeff MF, Hazeveld Y, Melker HE, Van der Wal MF, Nielen A, et al. A longitudinal study on determinants of HPV vaccination uptake in parents/guardians from different ethnic backgrounds in Amsterdam, the Netherlands. BMC Public Health [Internet]. 2017 Feb 21 [cited 2018 May 26]; 17(1):220. Available from: http://doi-org.ez17.periodicos.capes.gov. $\mathrm{br} / 10.1186 / \mathrm{s} 12889-017-4091-4$

42. Lee KN, Chang KH, Cho SS, Park SH, Park ST. Attitudes Regarding HPV Vaccinations of Children among Mothers with Adolescent Daughters in Korea. J Korean Med Sci [Internet]. 2017 Jan [cited 2018 May 26]; 32(1):130-4. Available from: http://doi-org.ez17.periodicos.capes.gov. br/10.3346/jkms.2017.32.1.130

43. Abou El-Ola MJ, Rajab MA, Abdallah DI, Fawaz IA, Awad LS, Tamim HM, et al. Low rate of human papillomavirus vaccination among schoolgirls in Lebanon: barriers to vaccination with a focus on mothers knowledge about available vaccines. Therapeutics and Clinical Risk Management [Internet]. 2018 [cited 2018 May 26]; 14:617-26. Available from: https://dx.doi.org/10.2147/ TCRM.S152737

44. Fernandes MC, Silva LMS, Silva MRF, Moreira TMM. Care management actions in the Family Health Strategy. Rev Rene [Internet]. 2015 Sept-Oct [cited 2018 Mar 02]; 16(5):664-71. Available from: http://www.periodicos.ufc.br/rene/article/view/2792

45. Queirós PS, Pires LM, Matos MA, Junqueira ALN, Medeiros M, Souza MM. Conceptions of parents of adolescent students about the sexuality of their children. Rev Rene [periódico na Internet]. 2016 Mar-Apr. [cited 2018 Mar. 02]; 17(2): 293-300. Available from: http://www.periodicos.ufc. $\mathrm{br} / \mathrm{rene} / \mathrm{article} / \mathrm{download} / 3043 / 2346$

46. Interaminense INCS, Oliveira SC, Leal LP, Linhares FMP, Pontes CM. Educational technologies to promote vaccination against human papillomavirus: integrative literature review. Texto Contexto Enferm [Internet]. 2016 [cited 2018 May 27]; 25(2):e2300015. Available from: https://dx.doi. org/10.1590/0104-07072016002300015 


\section{NOTES}

\section{CONTRIBUTION OF AUTHORITY}

Study conception: Carvalho AMC, Andrade EMLR, Nogueira LT, Araújo TME.

Data collection: Carvalho AMC.

Dana analysis and interpretation: Carvalho AMC, Andrade EMLR, Nogueira LT, Araújo TME Result discussion: Carvalho AMC.

Writing and/or critical review of content: Carvalho AMC, Andrade EMLR, Nogueira LT, Araújo TME. Review and final version approval: Carvalho AMC, Andrade EMLR, Nogueira LT, Araújo TME.

\section{ACKNOWLEDGEMENTS}

We thank Vera Lúcia Evangelista de Sousa Luz for developing the search and review strategy in the selection of articles herein included.

\section{CONFLICT OF INTEREST}

There is no conflict of interest.

\section{HISTORICAL}

Recebido: July 6, 2018.

Aprovado: December 12, 2018.

\section{CORRESPONDENCE AUTHOR}

Ayla Maria Calixto de Carvalho

aylamariacalixto@gmail.com 